\title{
Goat products: Meeting the challenges of human health and nutrition
}

\author{
Anaeto, M., J. A., Adeyeye, G. O. Chioma, A.O. Olarinmoye and G. O. Tayo \\ Department of Agriculture, Babcock University, Ilishan-Remo, Ogun State, Nigeria. \\ Correspondence authors: manaeto@yahoo.com
}

\begin{abstract}
The prospect of using small ruminants as food has not been fully exploited. Small ruminants produce food and fiber for man at a relatively low cost as they graze on pasture and feed on farm by - products. There are documentations on the benefits that can be derived from goat products regardless, of the breed or region. Goat meat is a source of high quality protein and low saturated fats which is good for human health. The use of goat meat and milk as therapeutic aids in heartrelated diseases and other ailments is unknown to many. This paper therefore, seeks to present goat as a good source of protein to help alleviate the protein nutritional deficiency of humans. The utilization of goat as experimental animal in researches, for medical purposes and other uses were also highlighted.
\end{abstract}

Keywords: Chevon, Goat, Milk, therapeutic

\section{INTRODUCTION}

Goat is a good source of meat (Chevon), milk, yoghurt, cheese and other by-products such as hide and skin. Goat population has witnessed a positive growth rate in the last 20 years (Morand-Fehr, 2003). The number of goats has increased by almost $50 \%$ at world level, cattle increased by just $9 \%$ whereas, sheep decreased by 4\% (Morand-Fehr and Boyazogly, 1999; Devendra, 2001). Thus, goat has emerged as one of the major livestock species rising in number. In Nigeria, the (Federal Ministry of Agriculture, 1997) reported 53.8 million herds of goats and this was more than sheep's 33.2 million and cattle's 18.2 million. Most of the goats and sheep predominantly thrive in the middle belt and northern areas of Nigeria. The three main breeds of goats recognized in Nigeria include: The West African Dwarf (WAD), Sokoto Red and West Africa longlegged goat or the Sahel (Bourn et al.1994). The WAD is the most common in the Southern part of Nigeria, because it is trypano-tolerant. The distribution of goat varies within region Norman (1991) noted that goats are concentrated in the drier region of Brazil, South Africa and Nigeria. According to Ibe (2000) Nigeria has not been able to provide animal protein in sufficient quantity to meet the dietary animal protein requirement of her citizenry. This protein deficit can be filled by rearing small ruminants, particularly goats. Goats are the most prolific of all domesticated ruminants under topical and subtropical conditions (Casey \& Van Niekerk, 1988; Webb \& Mamabolo, 2004). Goat does not only supply the family with protein, but can also be a source of livelihood generating income for the family. Also, Imasuen and Otoikhian, (2004) stated that goats play a very important role in the economy of countries such as USA, Britain and France that have been able to increase animal protein intakes because they are used as meat and dairy animals. Hence, the potential of goat should be harnessed to alleviate the protein nutritional deficiency in our society. The objectives of this review are to highlight some health benefits, nutritional values and the potential uses of goat.

Advantages of Raising Goat: The prospect of using small ruminants as source of food has not been fully exploited. According to Idachaba (2000) our local goats are the greatest scavengers. These species are prolific and multiply rapidly. We do very little to influence their production, yet they are always available to us on a daily basis. The following are some of the advantages of raising goats:

1. Goats are 'walking factories' producing food for man as they graze on pasture and farm by-products, thereby reducing the cost of weeding and feed cost. Goats can utilize pasture and forage which cattle find difficult to consume.

2. Goats have short generation interval. They are early maturing and can reach puberty as early as four months, while it takes the sheep six months. However, for better results, breeding should be delayed until the animal are eight months old. 
3. There are no religious restrictions regarding the raising of goats or the consumption of their milk, meat and other products, rather they are favoured by religious festivals and other social engagements.

4. Goat rearing serves as a source of income for the family.

5. Goats also increase the amount of animal protein consumed by the family.

Nutritional Value of Goat Products: Goat meat is a healthier alternative compared with other red meats. It has low saturated fatty acids and cholesterol as shown in Table 1. In the analysis of meat composition Devendra (1988) observed that the polyunsaturated fatty acids predominates in goat meat $(68.5 \%$ to $72.3 \%)$ and this is similar to the value of $69 \%$ reported by (USDA, 1989). A diet rich in nonsaturated fatty acids is correlated with a reduced risk of stroke and coronary diseases. Hence the American Heart Association recommends goat meat to people with heart-related problems. According to (Jamal, 2007), the molecular structure of goat meat is different and as a result goat meat is more easily digested. The wealth of documentary evidence indicated that goat meat (chevon), regardless of age, breed or region will supply a high quality protein source along with a healthy fat (increased unsaturated fat/ saturated fats ratio) with a minimal cholesterol intake risk. In addition, the amino acid profile is most important in terms of the indispensable amino acids provided. The amino acid profile of chevon shows a close resemblance with the analyses of beef, pork and lamb (Table 2). The usual limiting amino acids in various diets in various areas of the world are lysine, total sulphur amino acids, threonine and tryptophan and these are present in meat. According to Pellett and Young, (1990) the supply of amino acids is determined largely by the amount of protein in a particular cut of meat. It was noted further that meat is an important source of lysine, since $100 \mathrm{~g}$ lean meat would provide $30-59 \%$ of the total protein needs of an adult and $60-100 \%$ of the estimated lysine needs.
According to Haenlein (2000) research publications on how to feed goats better, breed them more efficiently and control their diseases better are academic. This information means little if the challenge to identify where goat milk and its products provide real benefits in human nutrition and why dairy goats are needed goes unanswered. The uniqueness of goat milk, yoghurt and cheese in human nutrition has several aspects, goat milk can be used for the treatment of direct or indirect cow milk allergy (Grezesiak, 1989). Goat milk has predominantly smaller fat globules compare to cow's milk and it is more easily digested (Fevrier et al. 1993). Hence, goat milk is a valuable alternative not just for babies, adults and especially nursing mothers (Baldo,1984; Host et al. 1988). The physiological and chemical facts of the unique quality of goat milk are just barely known and little exploited, especially the high levels of short and medium chain fatty acids which have recognized medical values for many diseases and disorders of people (Haenlein, 2004). Besides milk of cows, the animal that is most widely used to supply milk for human consumption is goat (Harren, 1994). The highest official production of milk by a dairy goat recorded in the USA was made by a Saanen doe that produced 6,500 lb of milk (Esminger, 1991). Goat milk protein differ in the amino acid composition and genetic polymorphism from the milk of other mammalian species (Jesnness, 1980; Boulanger et al. 1984; Addeo et al. 1988; Ambrosoli et al. 1988). The major protein in cow milk is alpha-s-I-casein, but goat milk may differ genetically by having either none ("Null type) or much ("High" type). The null type have shorter rennet coagulation time, less resistance to heat treatment, curd firmness is weaker, $\mathrm{P}^{\mathrm{H}}$ is higher and cheese yields are less than in high type. According to Zeman (1982) approximately 40 percent of all patients sensitive to cow milk proteins tolerate goat milk protein. The mineral content of goat milk is also higher as shown in Table 3, and these properties help to prevent iron deficiency anaemia and bone demineralization.

Table 1. Goat meat nutrition comparative chart

\begin{tabular}{llllll}
\hline $\begin{array}{l}\text { Per } \mathbf{3} \text { oz } \\
\text { Cooked/Roasted }\end{array}$ & Calories & Fat (g) & Sat Fat(g) & Protein(g) & Cholesterol(mg) \\
\hline Goat & 122 & 2.8 & .79 & 23 & 63.8 \\
Chicken (Skinless) & 162 & 6.3 & 1.7 & 25 & 76.0 \\
Beef & 179 & 7.9 & 3.0 & 25 & 73.1 \\
Pork & 180 & 8.2 & 2.9 & 25 & 73.2 \\
Lamb & 175 & 8.1 & 2.9 & 24 & 78.2 \\
\hline
\end{tabular}

Source: USDA Nutrient Data base for Reference 
Agric. Biol. J. N. Am., 2010, 1(6): 1231-1236

Table 2. Amino acid composition of muscle proteins of goat, beef, pork and lamb and beef collagen ( $\mathrm{mg}$ protein $\mathrm{g}$ )

\begin{tabular}{lccccc}
\hline Amino acid & Goat & Beef & Pork & Lamb & Beef collagen \\
\hline Aspartic acid & - & 88 & 89 & 85 & 43 \\
Threonine & 48 & 40 & 51 & 49 & 18 \\
Serine & - & 38 & 40 & 39 & 35 \\
Glutamic acid & - & 144 & 145 & 144 & 99 \\
Proline & - & 54 & 46 & 48 & 114 \\
Glycine & - & 71 & 61 & 67 & 187 \\
Alanine & - & 64 & 63 & 63 & 74 \\
Valine & 54 & 57 & 50 & 52 & 23 \\
Methonine & 27 & 23 & 25 & 23 & 8 \\
Cystine & - & 14 & 13 & 13 & 0 \\
Isoleucine & 51 & 51 & 49 & 48 & 15 \\
Leucine & 84 & 84 & 75 & 74 & 28 \\
Tyrosine & - & 32 & 30 & 32 & 67 \\
Phenylalanine & 35 & 40 & 41 & 39 & 21 \\
Histidine & 21 & 29 & 32 & 27 & 8 \\
Lysine & 74 & 84 & 78 & 76 & 30 \\
Arginine & 75 & 66 & 64 & 69 & 75 \\
Tryptophan & 15 & 11 & 13 & 13 & 0
\end{tabular}

Source: Pellett and Young (1990)

Table 3. Composition of the minerals and vitamins in human and goat milk

\begin{tabular}{lrr}
\hline Composition & Human & Goat \\
\hline Ca, mg/L & 280 & 1304 \\
$\mathrm{P}$ & 140 & 1080 \\
$\mathrm{Mg}$ & 35 & 136 \\
$\mathrm{Na}$ & 180 & 488 \\
$\mathrm{~K}$ & 525 & 1996 \\
$\mathrm{Cl}$ & 420 & 1566 \\
$\mathrm{Fe}$ & 0.3 & 0.5 \\
$\mathrm{Zn}$ & 1.2 & 2.9 \\
$\mathrm{Cu}$ & 0.25 & 0.23 \\
Vitamin A (RE) & 670 & 548 \\
Vitamin D microg/L & 0.55 & 0.6 \\
Vitamin E & 2.3 & -- \\
Vitamin K & 2.1 & 12 \\
Thiamin & 0.21 & 0.5 \\
Riboflavin & 0.35 & 1.4 \\
Niacin & 1.5 & 2.7 \\
Ascorbic acid & 40 & 12.6 \\
Panthothenic acid & 1.8 & 3.0 \\
Vitamin B6 & 0.093 & 0.5 \\
Vitamin B12 & 0.97 & 0.64
\end{tabular}

Source: D. L. O'Connor Small Rum. Res. 14(1994):143-149. 
Contribution of Goat Products to Human Health and Nutrition: According to Kues and Niemann (2004) farm animals have made significant contributions to human health and wellbeing thought mankind's history. The nutritive value of goat meat as well as other food items is becoming increasingly important in the health management of people. Addrizo (2000) stated that in an attempt to reduce heart diseases through diets, $80 \%$ of the patients who eat goat meat (chevon) had lower hyperlipemic state. Also, Nagura (2002) reported that people in Okinawa area in Japan have been eating goat meat as medicinal dishes for such purposes as recovering from fatigue and regaining physical strength during pregnancy and child birth. Goat milk contains much taurine, the substance added to health drink and revitalizers and there are reports that goat milk contributed to the treatment of diabetics. According to Haenlien (1996) the medical and paediatric literature has documentation on the treatment benefits with medium chain fatty acids in cases of mal-absorption syndromes, premature-infant feeding, cholesterolemia, gallstones, cystic fibrosis. In addition, goat milk fed to infants or children with digestive malnutrition has being found to be equal or even a superior substitute to cow's milk (Hachelaf et al. 1993; Razafindrakoto et al. 1993).

Other products and Uses of Goat: Goats were very valuable domestic animals to human in biblical days. They furnished milk for food, fibers for clothing, skin for bottles and served as the object of many sacrificial offering to Jehovah (Esminger, 1991). The by-products from goat include manure, hide and skin which can be processed into leather goods, blood meal for human and animal feed, horns, bones and hooves which are processed into many saleable products.

According to Provenza et al. (1983) the practice of using goats in bush control has been successful. Goats are used for the management of pasture weed control in the idle sloping land and vegetation management (Kitahara, 2002; Taylor, 2002). Goats are used as experimental animals for medical purposes, for measuring the digestion of forages and also as pack animals carrying weight of up to $25-30 \%$ of their body weight (King, 2004). Goat milk soap is a product with unique moisturizing cleanser. Goat milk soap is frequently recommended by dermatologists and used successfully to aid healing for people suffering from skin conditions such as psoriasis, eczema, acne and relief from dry, itchy skin (http://www.dionis goat milk skin care products).
The use of goats for pharmaceutical production: According to Kues and Niemann (2004) with the advent of transgenic technologies the potential of farm animals for improving human health is growing and many areas remains to be explored. Also, Rudolph (1999) stated that farm animal such as cattle, sheep, goats, pigs and even rabbits have several significant advantages for the production of recombinant proteins over other systems including their potential for large-scale production of pharmaceutical products. The drug called Aimspro made from goat blood offers hope to multiple sclerosis patients by improving their vision. It is the first time that any treatment has been shown to reduce an aspect of disability in the chronic phase of the disease. Matthews (2005) who led the trial said the results were encouraging. According to Anon (2009) it would be a scientific first, an anti clotting drug has been made from the milk of genetically engineered goats. The drug ATryn has already been approved for use in Europe. Up to now, anti thrombin has been produced from blood collected from human donors. ATryn is for use only when patients are undergoing surgery or having a baby, times when the dangers of clots is particularly high, the patients would receive the drug by intravenous infusion for a limited time before and after their procedures.

Efforts to Improve Goat Production: Sheep and goats are valuable in developing countries because of their ability to utilize scare feed resources and can tolerate unfavourable climate. Realizing the importance of goat to man, there has been various efforts at improving the stock. For example, the FAO Small ruminant program was put up to help small farmers to improve production. To aid research, FAO has built a computerized information network data base on their on going projects. Winrock international, USAID, ILRI, and other institutions are all geared towards promoting goat production. However, little is available on the use of goat models and organs for treating human diseases.

\section{CONCLUSION:}

Small ruminants as source of food has not been full exploited. Goat can survive and multiply under unfavourable climate. Also, the nutritional value of goat meat and milk is becoming recognized because of the medicinal values for treating many human diseases. 


\section{REFERENCES}

Addeo, F., Mauriello, R. and Luccia. A. D (1988). A gel electrophorectic study of caprine casein. J. Dairy Res. 55: $413-421$.

Addrizo, R. J (2000). Use of goat milk and goat meat as the therapeutic aid in cardiovascular disease www.Clemson.edu/agronomy/goat

Ambrosoli, R., Stasio, L. D. Mazzocco, P (1988). Content of alpha -s-I- casein and coagulation properties in goat milk. J. Dairy Sci. 71: 24 -28

Anon (2009). Anti clotting drug made from goat milk mark shift. wcbstv.com/health/anticlotting2.902006.html.USA.

Baldo, B.A (1984). Milk allergies . Austral J. Dairy Technol. $39: 120-128$

Boulanger, A., Grosclaude, F. and Mahe, M. F (1984). Polymorphism of caprine (Capra hicus) alpha -s- 1 and alpha-s-2 caseins. Geneticque Sel. Evol. 16:157175

Bourn. D., Wint. W. Blench, R. and Woolley, Z (1994) Nigerian Livestock Resource Survey. World Anim. Rev. 78 (1): $49-58$

Casey, N. H \& Van Niekerk, W. A (1988). The Boer goat. Origin, adaptability, performance testing, reproduction and milk production. Small Rum. Res 1: 291 -302

Devendra, C (1988). The nutritional value of goat meat. Proceeding (IDRC- 268e). goat meat production in Asia. March 13-18, pp 76-86

Devendra. C (2001). Small ruminants' imperatives for productivity enhancement, improved livelihoods and rural growth- a review. Asian-Austral. J Anim. Sci. 14 (10): $1483-1496$.

Esminger, M. E (1991). Animal Science Digest. Interstate Pub. Inc. USA

FAO, (1994). Production year book 1993 statistical series No.117

Federal Ministry of Agriculture (1997). Annual Report. Abuja, Nigeria.

Fevrier, C., Mourot, J., Jaguelin, Y., Mounier, A. \& Lebreton, Y (1993). Comparative digestive utilization of UHT goat and cow's milk: nutritional effects of galation-use of a swine model. Lait 73:581-592

Grezesiak, I (1989). Prescription of goat milk in Paediatrics -revolutionary. Le Concours Med. 111:3059-3064

Hachelaf, W., Boukhrelda, M., Benbouabedellah, M., Coquin, P., Desjeux, J.F., Boudraa, G and Louhami, M (1993). Comparative digestibility of goat versus cow's milk fats in children with digestive malnutrition. Lait 73:593-599
Haenlein, G. F. W (1996). Status and Prospects of the Dairy Goat Industry in the United States. J. Anim. Sci 74:1173-1181

Haenlein, G. F. W. (2000). Alternatives in Dairy Goat Product Market. www.goatworld.com

Haenlein G. F. W. (2004). Goat milk in human nutrition. Small Rum. Res. 51(2): 155-163

Harren, R. V. (1994). The Science of animal agriculture. Delmar Publisher Inc. Albany, New York. 122212.

Host, A., Husby, S and Osterballe, O. (1988). A prospective study of cow's milk allergy in exclusively breast - fed infants. Acta Paed. Scand. 77:663-670.

Idachaba, F. S. (2000). Topical Issues in Nigeria Agriculture: Desirable and workable Agricultural Policies for Nigeria. Inaugural Lecture. Department of Agricultural Economics University of Ibadan. Nigeria.

Imasuen, A. J. and Otoikhian, O. S. (2004). Growth and physiological performance of West Africa Dwarf goat reared under two different management Environment. In: Ogunji JO, Osakwe II, Ewa VU, Alaku SO, Otuma MO, Nweze BO (eds) Self Sufficiency of Animal Protein in Nigeria: A Reality or a Mirage. Proceedings of the $9^{\text {th }}$ Annual Conference of ASAN Nigeria held in Abakaliki, Nigeria. Innarrok Syndicate Publisher, 146148.

Ibe. S. N.(2000). Livestock Production in the South East Zone : Prospects and Strategies in the new millennium. Proceedings $14^{\text {th }}$ Annual Farming Systems Research and Extension Workshop in South-Eastern Nigeria. Umudike. Abia State

Jamal, S (2007). Fancy eating mutton? It is not goat meat http://bernama.com.my/bernama/v3

Jesnness, R (1980). Composition and characteristics of goat milk: Rev. J Dairy Sci 63:1605-1630

Kues, W.A and Niemann, H (2004). The contribution of farm animals to human health. Trends in Biotechnol . 22(6): 286-294

King, T (2004). Packing outlet changes breeding focus at Edelweiss Acres. Dairy Goat J. May-June. 2004

Kitahara, N (2002). Vegetation management by goat and educational functions of goat breeding. Farming Japan. 36(4): 14-15

Matthews P (2009). Goat blood drug 'offers Ms hope' www.BBCNEWHealthGoatblooddrugoffersMShope.'ht $\underline{m}$

Morand-Fehr, P. and Boyazogly, J (1999). Present status and future outlook of the small ruminant sector. Small Rum. Res. 34:259-269

Morand-Fehr, P (2003). Strategy for goat farming in the $21^{\text {st }}$ Century. Small Rum. Res. 51(2): 175-183 
Nagura, Y (2002). Utilization of goat milk and meat in Japan. Farming Japan. 36(4): 9-13

Norman, G.A (1991). The potential of meat from goat. Meat Sci. 5:57-87.

O'Connor, D. L.(1994). Folate in goat milk products with reference to other vitamins and minerals : A review. Small Rum. Res. 14:143-149

Razafindrakoto, O. Ravelomanana, N., Rasolofo, A Rakotoarimanana, R.D., Gourgue, P., Coquin, P., Briend, A and Desjeux, J.F (1993). Goat milk as a substitute for cow's in undernourished children: a randomized double -blind clinical trial. Lait 73:601-611

Rudolph, N.S (1999). Biopharmaceutical production in transgenic livestock. Trends. Biotechnol. 17:367-374.

Pellett, P. L. and Young, V. R (1990). Role of goat meat as a source of protein and essential amino acids in human nutrition. Meat Health Advances in Meat Research Vol. 6 (eds) Person, A. M and Dutson, T. R. Elsevier Applied Science, PP329=370
Provenza, F. D, Browns, J. E., Urness, P. J., Malachek, J. C and Butcher. H. E (1983). Biological manipulation of black brush by goat browsing J. Range Manage 36:513-518

Taylor C. A (2002). Using goats to control juniper. J Dairy Sci. vol. 85, suppl. 1/ www.adsa.org/jds/2002abs/nabs

USDA. Handbook (1989). \#8

USDA Nutrient Database for Standard Reference July (2001). Nutritional value of goat http://www.theikga.org/nutritional-value-of-goatmeat.htm

Webb, E. C. and Mamabolo, M. J (2004). Production and reproduction characteristics of South African Indigenous goats in communal farming system South Africa J Anim Sci. 34:236-239

Zeman, F. J (1982). Clinical nutrition and dietetics. Callamore Press, D. C. Health \& Co. Lexington, Massachusetts. USA. 